\title{
The Problem Resolution with "Almighty Key" for a Depressive Client
}

\author{
Fumie Sato ${ }^{1)}$
}

${ }^{1)}$ Sendai Branch, National Foundation of Brief Therapy

KEY WORDS: Depression, Brief therapy, Exception

\section{The Characteristics of the client}

The client was unmarried 35-year-old man. Although he had worked as a field overseer before the onset of depression, $\mathrm{He}$ was technical personnel at the point of the first session. His personality was serious-minded and well-organized and he had been taciturn since he was little. He had very few friends. His family structure consisted of his mother and his younger brother. His mother lived alone and she lived off her pension and the money sent by the client.

He had an onset of depression since five years ago and had sometimes taken leaves of absence from his job. At the point of first session, he had returned to work, however, he could not do his work well and felt alienated in his working place. He had also used to have his suicidal ideation. He still went to hospital and took antidepressants at that point. His main complaints were that he did not want to be like

CoRrespondence TO: SATO, Sendai Branch, National Foundation of Brief Therapy, 2-18-13 Cyomeigaoka, Sendai city, Miyagi, 981-3212, Japan

e-mail: ijbf@nfbt.org himself who used to be; He wanted to work in ways that he had worked before he got the disease; He wanted to have more conversations with his colleagues at working places.

\section{The intervention at first session}

After the therapist (the author) listened the client's narratives seriously, accepted his emotion, and empathized with him, the therapist let him search the positive sides of his life which is the "almighty key to solve the clients' problems".

\section{The second session}

Therapist (TH): Have you experienced any changes in your life?

Client (CL): I'm surrounded by good people.

TH: Last time you told that you were cold-shouldered, weren't you?

CL: I'm inconsistent, am not I? However, I've noticed that they show consideration for me.

TH: I think it is a good to realize that and you aren't inconsistent.

Besides, the client told that he could sleep without taking sleeping pills despite the fact that he took them at the point of the first session. 


\section{The intervention at second session}

The therapist suggested to the client that he takes a leisurely bath on Saturday night and consults with his doctor as to whether or not he may sleep without taking sleeping pills and suggested to him that he continue to search the positive sides of his life.

\section{The third session}

TH: Have you experienced something good?

CL: People around me care about myself. They speak to me, and I got praise from the assistant section manager. Now, I have come to be able to think positive. Currently, my main assignment is chores using the computer.

TH: Do you think you can do the field overseer?

$\mathrm{Cl}$ : I think I can do, though I can't understand some part of the job.

\section{The intervention at third session}

After giving the client positive feedback that he can recognize his current situation positively and he behaved to be praised by others, the therapist asked him to do more of searching the positive sides of his life.

\section{The fourth interview}

CL: I have experienced so many good things. Until now, I had been depressed because the people around me seem to be busy. However, I no longer experience such feelings.

TH: That's great. Then, can you afford to work a little bit more?

CL: It is still impossible for me.

TH: However, last time you told that you were in a fair way to return to the field. Do you have any reasons?

CL: Once, when I got depression, I was told by a colleague in front of the other colleagues that I don't want to work with such a guy, which made me depressed. As I had to work with him, I got depression.

TH: Why haven't you gotten depression this time?

CL: It is due to my so-what attitude thinking "I won't lose to such a guy", because the person is less skillful than me at the job.

TH: Great. You have been able to turn defiant, haven't you?

CL: Yes.

\section{The intervention at the fourth session}

The therapist conveyed the message that turning defiant is one of the almighty key to overcome the difficulties.

\section{The fifth interview}

CL: I have experienced many good things. I have gotten insured, I have lost my weight $1 \mathrm{~kg}$, and then, I have come to think that though the content of my job is ordinary this work will give the basis for other's work. Above all, I have come to think I am happy.

Adding to these remarks, the client had come to be able to care about the other colleagues, such as he worried about their depressive mood. 
Furthermore, he no longer felt alienated, he had come to speak to others spontaneously, think positive, and work as well as he worked before he got depression. He also has come to talk that his job is interesting. Given those facts, the therapist supposed that the original chief complaint had been solved. Besides, his insomnia symptom has also resolved. Therefore, the treatment had terminated at this session. 